\title{
Actual Methods of Translation of Culturological Content in Modern Teaching Russian Language
}

\author{
Alevtina D.Deikina* (a), Olga N. Levushkina (b), Olga Yu. Ryauzova (c). \\ (a), (b), (c) Moscow State Pedagogical University, 11943, Moscow (Russia), 1/1 Malaya Pirogovskaya \\ street, adeykina@list.ru
}

\begin{abstract}
At present, the social, economic, geopolitical, sociocultural conditions for the formation of the educational space are rapidly changing. Infocommunication technologies, on the basis of which the modern educational space is being reconstructed, makes it necessary to comprehend modern ways of transmitting cultural content in teaching the Russian language, which are caused not only by the placement of educational materials in a virtual environment, but also by adequate methodological tools.

In this regard, the purpose of this article is to identify the methods of broadcasting culturological content in teaching Russian as a foreign language that are relevant in the modern educational process, to identify the main aspects of the culturological content broadcast at the lessons of Russian as a foreign language.

To achieve the goal of the study, research methods were used such as a problem-comparative analysis of scientific theories, concepts and concept systems existing in linguistics and methodology, a generalization of the results of studies of the work of linguists, psychologists, psycholinguists, philosophers, cultural scientists, educators and linguistic and methodologists on the research problem.

The main methodological accents necessary for solving the identified problems are highlighted: aspects of cultural content are determined, which must be broadcast in the process of teaching the Russian language; methods of direct and indirect translation in the educational process are described and systematized; a possible methodological toolkit for working with cultural texts, relevant in terms of the use of information and communication technologies, is proposed. Broadcasting of cultural content in the methodology of teaching Russian as a foreign language today is possible by at least three methods described in the article: through direct personal influence of the teacher on students; by working with texts containing explicit cultural information; working with texts containing information about culture implicitly, and revealing it through the use of tools of linguistic and cultural characteristics of texts, especially artistic.

Effective ways of learning the culture of the language being studied by immersing the language itself will contribute to a more holistic and active development of it.
\end{abstract}

Keywords: teaching Russian as a foreign language, linguistic picture of the world, culturological content, methods of broadcasting culturological content, linguocultural characterization of a text, algorithm, modeling of textual activity.

* Corresponding author. E-mail: adeykina@list.ru 
(C) 2020 Alevtina D.Deikina, Olga N. Levushkina, Olga Yu. Ryauzova

This is an open access article distributed under the terms of the Creative Commons Attribution License (CC BY 4.0), which permits unrestricted use, distribution, and reproduction in any medium, provided the original author and source are credited.

Published by Kazan federal university and peer-reviewed under responsibility of IFTE-2020 (VI International Forum on Teacher Education)

\section{Introduction}

Modern educational content is characterized by special openness as a translating and transforming system of educational content (subject, communicative, professionally oriented, etc.). In the modern educational paradigm, which is characterized by an anthropocentric orientation, culture becomes the basis for perfection of the educational process. Nowadays education is interpreted as a form of translation of culture. At the same time, the digitalization of education opens up new possibilities in the ways of transmitting cultural content and requires rethinking of this problem. Cultural orientation brings methodological science into the space of true dialogue and world diversity (Mitrofanova, 1999).

The process of teaching the Russian language (as a mother tongue, as non-native, and as a foreign language) in this case is focused on the formation of reflected in the language and with the help of the language representation of the individual and society as a whole about the world, its structure, value system (Bolotnova, 2009) which is called the linguistic picture of the world.

Accordingly, the content of the educational discourse should also change, and it is advisable to include the general cultural concepts "world view" and "language world view". The resources of the Russian language make it possible to substantiate the essence of these concepts, especially if the Russian language is taught using an array of texts, including cultural content.

The study of the Russian language, combined with representation of Russian culture, allows to correlate linguistic norms and speech tools with communicative intentions in the cultural space of the language being studied, as well as to correlate foreign-language cultures in terms of similarities and differences. Broadcasting the cultural preferences of a foreign-speaking society is an opportunity to teach to understand foreign cultures (Gasparov, 2012). The ways of their broadcasting are always determined by the era, its capabilities, and the worldview of members of society.

The rapidly changing social, economic, geopolitical, sociocultural conditions for the formation of the educational space, the infocommunication technologies, on the basis of which the modern educational space is being reconstructed, make it necessary to comprehend the modern ways of transmitting cultural 
content in teaching the Russian language, which are caused not only by the placement of educational materials in a virtual environment, but an adequate methodological tools.

The issues discussed in this study are classic questions about WHAT to broadcast and HOW? What are the main aspects of the cultural content of the lessons of Russian as a foreign language?

What methods of broadcasting culture to foreign students are used by a modern teacher who has integrative knowledge and skills in the field of linguistics, psychology, cultural studies and linguoculturology, pedagogy and methodology?

What methods of personal influence does a teacher use to broadcast cultural content? What modern methodological tools can be used for this purpose?

\section{Purpose and objectives of the study}

The purpose of this study is to identify and describe relevant ways of translating cultural content in the modern process of teaching Russian as a foreign language, to outline the main aspects of cultural content broadcast in the lessons of Russian as a foreign language.

\section{Literature review}

The transfer of cultural experience in the field of the language being studied, definitely, should be meaningful in relation to the real conditions of the modern moment and an adequately new sociocultural and educational environment. It cannot be ignored that the verbal behavior of persons in the modern model of education has become more dialogical than before, changes are taking place in the style and methods of presentation of the material, the tendency to use media texts is becoming more pronounced.

To broadcast a culture means to make it known: for foreign students it will become clearer what is indicated by the Russian language and is transmitted by its means in the communicative educational process, and then in professional activity, if an adequate cultural background is provided. To broadcast Russian culture in the context of studying Russian as a foreign language means to popularize its most significant manifestations.

Communicating the values of another culture and on this background learning another language is that cultural vaccination that allows speaking about tolerance as a necessary general quality, expanding the cultural horizon of students, and contributing to the correct understanding of utterances in the communication process. 
Statements in one or another language are "means belonging to language and culture in a certain era". Obviously, the teacher of Russian language, who broadcasts culture, has at his disposal the most powerful tool - language. It is through words that the picture of the world is structured. Words are the background on which we see any action. They are subjective, evaluative in nature and determined by culture (Barden \& Williams, 2007). And it is very important at the early stage of teaching Russian as a foreign language, not only to teach how to use the necessary words that correspond to communication situations, but also to lay the foundation that will allow students to feel the relationship, and even kinship with the Russian language, with Russian culture, with other people, with the world.

Language is a mental dominant that defines the picture of the world, a mental tool with tremendous potential: it is used in the process of teaching, transmitting knowledge, generating emotions, nurturing a person. Language forms space, "collects" life into words. However, texts are the capacitors of cultural memory and the true guardians of culture (Lotman, 2004). The role of the text-centric approach in a culture-oriented teaching of the Russian language cannot be overestimated.

It is the work with the text that provides the broadcast and relay of culture, the commentary on the text helps to maintain the continuity of tradition, to connect the present with the past and the future, helps to increase knowledge, and forms the meta-subject of the results. The modern text-centric approach actualizes the cognitive learning problem, i.e. not only the acquisition of knowledge, but understanding of the essence of the studied subject, phenomenon, unit of language, speech and culture (Deikina, 2016).

\section{Methodology}

This study is generalizing methodological in nature, it describes the methodological possibilities of solving one of the most important problems in teaching Russian language - the integration of language learning processes and understanding the culture of native speakers of the studied language.

To achieve the goal of the study, research methods were used such as a problem-comparative analysis of scientific theories, concepts and conceptual systems that exist in linguistics and methodology, a generalization of the results of studies of the work of linguists, psychologists, psycholinguists, philosophers, culturologists, educators and linguistic and methodologists on the research problem.

The materials of this study were widely tested in the process of training and retraining of specialists in the field of teaching Russian as a foreign language, in publications in peer-reviewed Russian and foreign publications, in dissertation works, in speeches at international conferences, congresses and forums. 


\section{Results}

In modern linguodidactics ways of organizing textual activity purposefully built on the basis of texts containing a variety of information about culture come to the fore. Getting acquainted with the texts of cultural orientation, a person through the language comprehends the national foundations, enters the mental space of the nation.

In the practical age of utilitarian knowledge, the Russian language not only serves a variety of areas of professional activity, but is also responsible for cultural communication, in which something is determined by the human mind, and something by feeling. We are talking about the aesthetic sense of man created by art, including the art of the word.

The literature of world-wide recognition is written in Russian. "Literature meets the human need for beauty," wrote Gasparov (2012). By transmitting cultural content, it is necessary to teach a language such as Russian to ensure a harmonious balance of pragmatic and aesthetic trends, which can be achieved by working with texts that express cultural information in different ways: cultural history and art history, on the one hand, and culture texts - with another.

Cultural and art texts contain information about a culture of informational nature. The cultural history text "aims to interpret the artifact used in the lesson (painting, sculpture, music, decorative and applied art), expand the cultural horizons of students, serve as a model of expression, enrich students' speech with words with a cultural component, art terms and vocabulary, used in the socio-cultural sphere. (Hodyakova, 2005)

An art history text is a text written by an artist, art historian, teacher, visual art teacher, which directly describes the content of a particular painting and means of expressing the artist's intention, evaluates the merits or criticizes the shortcomings of a work. (Hodyakova, 2000).

Such methods of broadcasting cultural content in the educational process are indirect, as they are embedded in the educational process in accordance with the methodological considerations of the teacher. Cultural and art history texts contain explicit information about the culture, openly broadcast cultural content.

A culture text differs from previous types of texts in that it may not contain direct information about the culture, but express it indirectly, implicitly. The text of a culture is called "a text belonging to a certain culture, created within its framework and reflecting this culture to one degree or another. (Novikova, 2005). 
For educational purposes, the study of Russian as a foreign language, it is important to answer the acute question of the selection of cultural content, which in the process of teaching Russian as a foreign language can create a foundation of understanding in the dialogue of cultures.

The desire to take into account in the methodology of teaching the Russian language the process of the formation of a value attitude to language and culture as phenomena is justified in a number of scientific studies (Deikina \& Levushkina, 2014; Bystrova, 2002; Donskaya, 1999; Hodyakova, 2000; Prosvirkina, 2012; Kulaeva, 2008).

The process of axiologicalization of education actualizes attention to the value properties of the native language, which manifests itself primarily in texts as mental-value sources in the study of the Russian language motivates the understanding that the ideas of axiological education of students are directly related to work on the text as linguodidactic and linguocultural unit (Deikina, 2019).

The issues of cultural orientation, cultural preferences and cultural competence in teaching Russian as a foreign language are most often considered in connection with the interest in the social realities in the country of the studied language and preparation for professional activities, in combining linguistics and cultural studies as an object of controlled knowledge and representations during the testing process, taking into account the linguistic and cultural environment of the university (Korotyshev, 2017).

The author's methodological strategies for the formation of linguoculturological competence of foreign students of different profiles are described in dissertation researches. (Bezhenar 2017; Tsotova, 2017; Bolotov 2017; Korotyshev, 2017).

Obviously, scientific research is multidirectional in nature and does not reveal the overall systematic work of translating cultural content in teaching Russian as a foreign language. At the same time, another thing is obvious: a substantial update of scientific ideas about various aspects and components of the cultural experience of the country being studied is based on such scientific fields as axiology, cognitive science, linguoculturology, etc. (Khasanova, 2014; Bert, 2019; Mizin \& Korostensky, 2019; Deberdeeva \& Voichenko, 2017; Ten \& Gudakov, 2015).

\section{Discussions}

A wide interdisciplinary context is characteristic of the problems of linguocultural direction. This study area of linguoculturological research is called applied linguoculturology, which is mainly associated with the educational process, the study of the Russian language in a foreign audience (Guzman, 2008). 
The methodological basis of such studies should be the culture-shaped philosophy of modern higher education and a system-integrated approach, through which unity, interdependence and mutual influence of the studied language and culture with its core, the language, can be ensured.

Researchers have successfully proved that the Russian language as a cultural phenomenon opens up new horizons for the bilingual or multilingual child for his creative self-realization and creates an attractive and promising alternative, that to achieve the goal of successfully mastering Russian as a foreign language and as a cultural phenomenon, a synthesis of cognitive and students' creative activity (Mardakhaev, Egorychev, Varlamova, \& Kostina, 2018).

At the same time, modern research is aimed at the implementation of specific tasks related to the cultural aspects of education: the development of educational technologies aimed at the development of certain personal qualities of students, indicating the formation of a linguistic and cultural personality of a future teacher (Mizin \& Korostenski, 2019) the identification of a paradigmatic value system that affects the formation of a person in traditional culture (Ivanov \& Ivashchenko, 2018) analysis of the development of the value-semantic sphere of the personality of the student in a multicultural environment the formation of his culturological position (Uaikhanova \& Ushakova, 2019) and others.

In this article, as an innovative methodological tool for linguocultural development and linguocultural adaptation of students, the linguocultural characteristics of the text are proposed (Deikina \& Levushkina, 2014).

This methodological tool is used when working with cultural texts in the methodology of teaching Russian as a native language, as non-native and as a foreign language based on working with text as an integral unit of language, speech and culture.

The innovativeness of the methodological tools of the linguoculturological characteristics of the text lies in the fact that it is integrated into almost every lesson of the Russian language, realizing functional and linguoculturological approaches to teaching the Russian language, and is used in different formats: methodological (as a method of teaching the Russian language), technological (as a type of educational activities) that implements (as a type of school essay).

In the methodological format, the linguoculturological characteristic of the text is a tool of the teacher, allowing you to teach the understanding of the text as an integral unit of language, speech and culture, the disclosure of its linguocultural potential. This method is active (as it implies the active activity of students), comprehensive (since it implies a complex of analytical, synthetic and evaluative types of educational 
textual activity, the use of a complex of various types of text analysis, etc.), integrative (since the interpretation of the text relies on the integration of awareness students in various fields of knowledge), to a certain extent universal (as it allows, when working with texts, primarily artistic ones, to reveal an objective general culture hydrochloric information and individual cultural meanings).

The linguoculturological characteristic of the text allows to simulate the educational and cognitive activities of students, to build the structure of the Russian language lesson depending on its purpose, content, volume and quality of the language and speech material. The use of this method allows to stimulate the cognitive process, motivate students to learn the Russian language in conjunction with culture, to exercise control and self-control in the lessons of the Russian language.

The technological format of this tool is determined by the communicative model "author - text - reader" and is implemented as a type of educational activity, which is modeled depending on the given conditions (style and type of text, educational tasks, material to be studied, volume of tools used for linguocultural characteristics of the text, etc.) based on the proposed algorithms.

In this case, educational textual activity is aimed at revealing the linguoculturological potential of the text being studied, and using of the methodological tools make it possible to organize research and search activities of students aimed at understanding not only superficial, but also deep, cultural, meanings of the text. The change in the types of textual activity is determined by an algorithm that determines the sequence of types of textual activity: receptive, analytical, synthetic, interpretative, reflective, productive.

The presence of reflective, evaluative activity in the technological model of linguocultural characteristics allows students to express their own attitude to the revealed meanings of the text, to the position of the author, expressed in the text, which generally contributes to the assimilation of students spiritual and moral guidelines, the formation of their value base, worldview as a whole. The realizing format of the linguoculturological characteristics of the text is based on the author - metatext - recipient model and is determined by three compositional components of the essay created by students that reflect, firstly, the understanding and interpretation of the surface and deep meanings of the text; secondly, understanding and interpretation of the author's position; thirdly, the expression of one's own attitude to the substantial aspects of the text and ways of expressing the author's attitude to them.

Thus, the use of linguoculturological characteristics when working with text in the process of teaching the Russian language contributes to the enrichment of the arsenal of textual skills of students, allowing them to master new cultural experiences, to discover the culture of the people in the bosom of which these texts were created. 
In the prospect of new research, the potential of the concepts of foreign-language cultural and linguistic education related to the comprehension and cognition of sociocultural norms, various sociocultural components (subject, information, communication, etc.), the specificity of intercultural communication, spiritual values and cultural traditions can be emphasized, features of the national mentality of native speakers of the Russian language. Rhetorical canons of Russian speech, features of speech etiquette, cultural map of Russia, etc. are of great interest.

A teacher, as a bearer of his own culture, broadcasts cultural content on a personal level, possessing certain personal qualities, as well as linguistic, psychological, cultural, pedagogical, methodological and other knowledge and skills that make up his professional competence.

Translation of cultural content in teaching Russian as a foreign language requires consideration of another important issue - the personal characteristics of the teacher. What qualities should a teacher of Russian have? What qualities are dominant, create his professional portrait, make him special, individual, unique?

The teacher must be a spiritual and moral person, an exemplary representative of Russian culture, he must form a holistic view of Russian culture, based on national traditions, as well as know the culture, features, traditions of those countries of which he teaches Russian.

The broadcast of cultural content also depends on a psychologically comfortable environment that motivates further immersion in the Russian language and Russian culture.

What happens to a person who finds himself in a new sociocultural environment? How long will the period of its adaptation be? And what will be the attitude to language and culture? Of course, it all depends on the teacher, focused on the transfer of their own knowledge, feelings, perception of the world. And only a person who is not indifferent, realizing the significance of his profession, having a wide intellectual horizon, is able to convey love for the Russian language and culture, "fall in love" with that new sociocultural environment that will be accepted by the student, ensure his mental health and satisfy the necessary non-material needs.

Among the five basic needs identified by Maslow back in the 1940s that a person needs for a sense of psychological comfort, the scientist singled out the need for belonging and love, which implies a relationship with family, work group, a sense of closeness and understanding in relationships.

It seems that these factors can be attributed to a foreign student, building a new image of the world for him, and this is the image of the house. The question arises: how to create such a house in the educational 
environment, reflecting the diversity of the world, the field of human life? How to combine linguistic, cultural and mental spaces?

An teacher of Russian, being a professional, must be sensitive to the uniqueness of each individual participant in the educational process and integrate cultural content into an intersubjective educational space, since the relationship with the language is a reflection of emotional life patterns (Barnes, 2001) and human life is permeated with emotions.

\section{Conclusion}

We list the main components of the cultural content that are important not to miss in the process of teaching Russian as a foreign language. The first steps towards mastering the language are related to acquaintance with Russian speech etiquette, as in the life of any society, in business or everyday communication, the culture of behavior and communication plays a big role. The anthropocentric orientation of etiquette emphasizes Formanovskaya (2002): it reflects that part of the real world that is associated with a person in his attitude to other people and etiquette-significant things. Etiquette involves the establishment of relationships between people, the construction of certain (official / unofficial) relationships. Units of speech etiquette, appropriate situations, just perform this function.

Familiarity with Russian customs and traditions should also be included in the content of cultural material. Russian traditions are not typical for other cultures can cause misunderstanding and even suspicion in some situations.

It is also important to discuss with foreign students issues that reflect the attitude of Russian people to family, friends, and colleagues. It is known that in different cultures there are forbidden topics that violate the laws of interpersonal communication.

The inner world of man by invisible threads is connected with nature. Under the influence of the natural forms surrounding a person from childhood, aesthetic models of beauty are formed, ideas about graceful, perfect, harmonious and expedient are accumulated. Moreover, each nation has unique beauty models due to the uniqueness of their native environment. Therefore, texts on the moral and aesthetic aspects of the relationship between man and nature should also be reflected in the educational process. They allow to cover this topic from different angles: to show the infinity of Russia, the diversity of natural zones, the specifics of life in different parts of the country, to discuss the problems of water resources, global environmental problems of our time, to consider the attitude to mother earth, to bread (Bread - everything's head.), botanical gardens, nature reserves and much more. 
And the study of texts taken from literary works will help to penetrate the secrets of the Russian soul. Russian literature, history, architecture, music have long been presented in textbooks and manuals aimed at foreign students, but the content component requires some revision, updating. It seems logical to include in the text corpus fragments reflecting the spiritual and moral characteristics of famous people who have contributed to the development of national culture.

\section{References}

Barden, N., \& Williams, T. K. (2007). Words and symbols. Language and communication in therapy. New York: McGraw Hill.

Barnes, G. (2001). Voices of sanity in the conversation of psychotherapy. Melbourne: Kybernetes.

Bert, P. (2019). On Linguoculturology and Cultural Linguistics. Bulletin of NSU, Series: Linguistics and Intercultural Communication, 17(4), 6-11.

Bezhenar, O. A. (2017). An ethnic-oriented model of teaching the Russian language to Italian-speaking students outside the language environment (PhD Dissertation). Moscow: People's Friendship University of Russia.

Bolotnova, N. S. (2009). Communicative style of the text: vocabulary-thesaurus: a textbook for students of higher educational institutions studying in the field of 050300 Philological education. Moscow: Nauka.

Bystrova, E. A. (2002). Dialogue of Cultures on the Russian language lessons: Guide for the development of speech for 7-9 grades of a comprehensive school. Saint Petersburg: Prosveschenie.

Deberdeeva, E. E., \& Voichenko, V. M. (2017). Metaphor as a means of organizing a linguistic picture of the world in Russian and English linguistic cultures. Russian linguistic bulletin, 2(10), 3-5.

Deikina, A. D. (2016). The methodical culture of the vocabulary in the modern linguo-educational situation. Russian language at school, 6, 3-5.

Deikina, A. D. (2019). Axiological Methods of Teaching the Russian Language: Monograph. Moscow: Moscow State Pedagogical University. 
Deikina, A. D., \& Levushkina, O. N. (2014). The methodological potential of linguoculturological characteristics of the text in school teaching of the Russian language. Russian language at school, 4 , 12-16.

Donskaya, T. K. (1999). Ocherki po metodike russkogo yazyka [Essays on the Russian language methodology]. Saint Petersburg: Sudarynya Publ.

Formanovskaya, N. I. (2002). Russian speech etiquette: normative socio-cultural context. Moscow: Russian language.

Gasparov, M. L. (2012). Philology as morality. Moscow: Fortuna EL.

Guzman, T. R. (2008). The problems of linguoculturology discussed on the pages of the "Russian language studies". Russian language studies, 16(4), 380-397.

Hodyakova, L. A. (2000). Painting at the lesson of the Russian language: Theory and methodological development of lessons: a manual. Moscow: Nauka.

Hodyakova, L. A. (2005). Realization of the cultural potential of painting at lessons in the development of speech. Formation of cultural competence of students in teaching the Russian language. Moscow: Prometheus.

Ivanov, A. A., \& Ivashchenko, S. Ya. (2018). Axiology of human formation in traditional culture. Bulletin of the Novosibirsk State Pedagogical University, 8(6), 236-249.

Khasanova, S. (2014). Lingua. Cultural aspect of the relationship between language and culture. International journal of English linguistics, 4(6), 160-166.

Korotyshev, A. V. (2017). The technology of selection and linguodidactic adaptation of literary texts in order to teach Russian as a foreign language ( $\mathrm{PhD}$ Dissertation). Moscow: Moscow State University.

Kulaeva, G. M. (2008). Aesthetic ideal in the system formatting values of pupils who study in the Russian language (Doctoral Dissertation). Moscow: Moscow State Pedagogical University.

Levushkina, O. N. (2016). We develop speech and teach understanding of the text: a toolbox of linguoculturological characteristics of the text in the Russian language lesson. Slavistics, 20, 422426. 
Lotman, Y. M. (2004). Universe of the mind. Saint Petersburg: Iskusstvo-SPB.

Novikova, L. I. (2005). The cultural history aspect of teaching the Russian language in grades 5-9 as a means of comprehending students of national culture (Doctoral Dissertation). Moscow: Moscow State Pedagogical University.

Mardakhaev, L. V., Egorychev, A. M., Varlamova, E. Y, \& Kostina, E. A. (2018). Development of linguocultural personality of future teachers withing the educational environment of higher educational institutions. Novosibirsk State Pedagogical University Bulletin, 8(4),204-216.

Mitrofanova, O. A. (1999). Linguodidactic lessons and forecasts of the XX century. Reports and messages of Russian scientists, 253-261.

Mizin, K., \& Korostenski, J. (2019). "Western” Cultural Linguistics and "Post-Soviet" Linguoculturology: Causes of parallel development. Linguistic Studies, 37, 7-13.

Prosvirkina, I. I. (2012). Hidden Meanings. Speech Communication. Bulletin of Orenburg State University, $11,116-119$.

Ten, Y. P., \& Gudakov, V. V. (2015). Symbols of the regional culture of the North Caucasus. Science almanac of Black Sea region countries, 2(2), 39-47.

Tsotova, D. Yu. (2017). Teaching Russian as a foreign language at courses outside the language environment using linguistic theories (PhD Dissertation). Belgorod: Belgorod State University.

Uaikhanova, M. A., \& Ushakova, N. M. (2019). Nurturing cultural attitudes within the framework of multicultural education. Science for Education Today,9(2), 212-214. 